\title{
On the Management of College Students under the Concept of "Cultivating Morality and Cultivating People"
}

\author{
Shaoqin Liu, Xin Wang, Jinzhe Chu \\ Heilongjiang Bayi Agricultural University, Daqing, China \\ Email: 251550931@qq.com
}

How to cite this paper: Liu, S. Q., Wang, X., \& Chu, J. Z. (2020). On the Management of College Students under the Concept of "Cultivating Morality and Cultivating People". Open Journal of Social Sciences, 8, 438-446. https://doi.org/10.4236/jss.2020.86033

Received: June 1, 2020

Accepted: June 25, 2020

Published: June 28, 2020

Copyright $\odot 2020$ by author(s) and Scientific Research Publishing Inc. This work is licensed under the Creative Commons Attribution International License (CC BY 4.0).

http://creativecommons.org/licenses/by/4.0/

\section{(c) (i) Open Access}

\begin{abstract}
In the report of the 18th National Congress of the Communist Party of China, it is proposed that colleges and universities should take the theoretical system of "cultivating morality and cultivating people as the fundamental task of education" as the guidance center. The basic concept of "cultivating morality and cultivating people" has become the main guiding ideology for universities in China to carry out student work. While cultivating professional talents for the country, universities also shoulder the task of cultivating and inspecting the comprehensive quality of talents and are committed to cultivating comprehensive talents with all-round development of morality, intelligence, physique, arts and labor. Therefore, it is of great value and significance to explore the innovative modes and practical methods of student management in colleges and universities under the concept of "cultivating morality and cultivating people". Under the theoretical system of "cultivating morality and cultivating people", colleges and universities actively explore new paths, new forms and new methods of student management.
\end{abstract}

\section{Keywords}

Cultivating Morality and Cultivating People, Student Management, Colleges and Universities

\section{Introduction}

At the national congress, general secretary Xi Jinping highly summarized the important position of education in the new era with "the great plans of the country and the party". It is also the most urgent fundamental problem to be solved in China's colleges and universities today that "who should be trained, how to train and for whom". The cultivation of students in colleges and univer- 
sities lies not only in the cultivation of professional skills, but also in the all-round cultivation of students' ideological and moral qualities, ideals and beliefs, and moral sentiments. The management of educational students in colleges and universities should stick to the initial aim of teaching and educating people and the mission of cultivating moral character and cultivating people (Chen, 2019). With the comprehensive reform of higher education and the rapid popularization of Internet information technology, all-round education is bound to become the new direction for the future development of higher education in our country, which will certainly bring many new changes and challenges to the management of college students. In order to further realize the development goal, the management of college students must stick to the fundamental mission of "cultivating morality and cultivating people".

\section{The Meaning of "Moral Cultivation"}

A country without virtue is not prosperous, and a person without virtue is not established. The foundation of educating people lies in moral cultivation and soul building. "Cultivating Morality and Cultivating People" is the central guiding ideology in the management of college students in our country. "moral cultivation" means that in the overall talent training and assessment system, colleges and universities should always adhere to the principle of taking students as the foundation, strengthen the ideological and moral education of students, adhere to the ideological and moral education in the first place, cultivate students' correct three views, and shape students' sound personality (Guo, 2019). In the management of students, the "moral" colleges and universities must first firmly hold their students' ideals and beliefs, cultivate their patriotism, guide them to shoulder the burden of the times, educate them to set up lofty communist ideals, and train builders and successors with both ability and political integrity for the country.

\section{The Contents of College Student Management}

On December 16, 2016, the Ministry of Education promulgated the newly revised "Regulations on the Administration of Students in Colleges and Universities". The promulgation of this regulation has played an important role in starting and demonstrating the implementation of student management in colleges and universities. The management of students in colleges and universities refers to all daily management matters from the time of admission to graduation, involving the daily management of students, student status management, campus culture construction, party and group class construction, termination of rewards and sanctions, mental health education, career planning and employment guidance, student complaints and many other aspects. In terms of the current form, we often say that student management refers to various forms of work such as cultivating students' innovative and entrepreneurial spirit, voluntary service awareness, practical skills, and social practice ability. The ultimate goal of college 
student work is to cultivate high-quality talents in an all-round way. The idea of student work in colleges and universities is to focus on the construction of party members' groups and comprehensively promote the status of ideological and political education: to take the style of study and sleeping style as the guidance, to create a good learning atmosphere and bedroom environment; to take the construction of campus culture as the starting point, to comprehensively improve the comprehensive quality of students; to take the school system as the basis, to enhance the echelon construction of student work team; to take social practice and voluntary service as the basis, to cultivate students' service consciousness and labor ability (Xu, 2019): Relying on career planning and employment guidance to improve the employability of students: brand activities and scientific and technological innovation as a platform to cultivate comprehensive talents with outstanding professional skills. The concept of student work is the basis for colleges and universities to carry out student management work and has the function of guiding and standardizing students' daily behaviors.

\section{The Management of College Students Insists on the Importance of "Cultivating Morality and Cultivating People"}

In our country's education system, the management of college students involves the management and construction of students' "second classroom" report cards. Education plays an important role in guiding students' ideological progress and urging students to develop in an all-round way. It is also an important guarantee for maintaining campus security and stability and harmonious social development. With the continuous development of the social and economic system, the management system for college students in our country has been gradually improved. The ideological and political education of college students is advancing steadily, the construction of campus culture is becoming more and more diversified, the achievements of scientific and technological innovation are rising year by year, the employability of students is getting stronger and stronger, and the management of college students is in a new period of rapid development. At present, China's economy is in a period of rapid development. With the impact of diversified ideas, rich economic chains, popularization of Internet information technology, complicated international situation and various cultural values, the management of college students is facing challenges. At the same time, it is particularly important to guide the management of college students with the concept of "cultivating morality and cultivating people." (Jing, Yang, \& Teng, 2019).

\section{Problems Existing in Student Management under the Concept of "Cultivating Morality and Cultivating People"}

\section{1. "Passive" Management Model Hinders Students' Development}

Under the influence of new media, college students' world outlook, outlook on 
life and values are increasingly diversified ( $\mathrm{Hu} \& \mathrm{Si}, 2019)$. The rapid development of new media and the widespread acceptance and use of new media by college students have prompted the ideological and political education of college students to change from the original closed, semi-closed state to the open state, which has continuously broken the traditional education mode (Yi, 2019). With the rapid development of social economy and the popularization and application of mobile Internet technology, the proportion of Internet's influence on college students has increased year by year. The diversified, complex and changeable information on Internet platforms has changed the ideological and behavioral concepts of college students. Mandatory management modes such as "being watched", "being involved" and "being enrolled" make students "passive" and have strong rebellious mentality. They lose hope and yearning for a beautiful campus life and become depressed and depressed in their daily learning and life. The "passive" student management form in colleges and universities greatly limits the implementation of the concept of "cultivating morality and cultivating people" (Xu, 2019). Students' work management personnel follow the rules and regulations with loopholes to manage students. It is easy to ignore students' feelings and affect students' growth and development. It plays a blocking role in cultivating all-round talents.

\subsection{The Complexity of Campus Cultural Environment Affects Students' Ideological Changes}

With the rapid development of new media technology, the Internet, as the main platform and media for information dissemination and flow, has the characteristics of diversity, diversity and complexity in the information it transmits, College students are also the new force of the Internet platform, so the spread and diffusion of Internet information has an important impact on college students' outlook on life, world outlook and values. The impetuous network environment makes college students' thoughts complicated, their personalities changed, and they became irritable and irritable. In the daily study and life on campus, some students often fight against each other due to a trivial matter, regardless of the consequences. The problem of integrity in examinations has been repeatedly tested. What's more, there have been some undesirable phenomena such as irresponsibility of school teachers' management and abuse of teachers. This kind of bad result has something to do with the quality of the students themselves, but it is more closely related to the school management system (Chen \& Li, 2019).

\subsection{Incomplete Management System Hinders Students' All-Round Development}

The purpose of student management in colleges and universities is to train students to develop in an all-round and coordinated way. However, there are still some problems in the student management system in colleges and universities, which need to be further improved. The problems of "passivity", "compulsion" and "patternization" in the process of student management need to be properly 
solved by colleges and universities. The customization and implementation of student management system in colleges and universities should focus on the practical problems faced by colleges and universities and the actual situation of students, From the perspective of reality and "three-in-one" education, close to students' daily life, understand the problems encountered in students' learning and life, and thus make the reform and improvement of the management system, in order to truly play the exemplary role of "cultivating morality and cultivating people". The personnel engaged in student management in colleges and universities attach great importance to the cultivation and construction of the backbone of students, while ignoring the cultivation and care of ordinary students, gradually dividing the backbone of students and ordinary students into two camps, the backbone of the students has become the executor of the management system, and the ordinary students have become the passive bearers of the system, which has imperceptibly drawn a distance gap and is not conducive to the all-round development of college students (Wang \& He, 2018).

\section{New Ideas of Student Management under the Concept of "Cultivating Morality and Cultivating People"}

\subsection{Building Communication Platform between Teachers and Students and Broadening Feedback Channels for Students}

Maintaining a continuous, smooth, rich and unimpeded interactive channel of information exchange between teachers and students is an important link in improving and perfecting the management of students in colleges and universities. Feedback from the results achieved through multi-channel communication is often more practical than the results obtained in formal occasions or symposiums, and can give feedback on the fundamental problems faced by students. Therefore, colleges and universities should continuously develop and innovate in student management work, focusing on building a platform for communication between teachers and students, and broadening the channels for students to feedback information. At this stage, the Internet and new media technologies are in a period of rapid development, which also provides a variety of platforms and channels for interaction between teachers and students in colleges and universities. Colleges and universities can rely on the Internet to create teacher-student feedback modules and principal mailboxes on the official homepage, build interactive communication platforms on official microblogs, publicity and posts, and set up feedback boxes in student apartments and teaching buildings to solicit students' opinions and suggestions, however, in the process of feedback information processing, colleges and universities should avoid the phenomenon of "one voice" and deal with problems fairly, fairly and openly, so as to maximize the effect of information feedback communication, and improve the student management system in continuously receiving opinions and adopting suggestions, let students take the initiative to participate in the management of the school, changing "passive" into "active", promoting students' understanding of 
the rules and regulations, urging students to abide by the school rules and regulations, and finally the management system was unanimously approved by the school teachers and students (Chen \& Li, 2019)!

\subsection{Strengthening the Construction of Campus Culture and Creating a Good Education Environment}

Campus culture plays a more significant role in educating and guiding students. It can provide an effective platform for ideological and political education of college students and must be set off by corresponding red cultural atmosphere and scenes (Wang \& He, 2018). Colleges and universities shoulder the important mission of training builders and successors for the country. They must always carry out campus culture construction projects with greater efforts and make unremitting efforts to train a large number of high-quality comprehensive talents for the country. At the same time, colleges and universities should pay attention to the construction of campus culture, which plays a key role in the cultivation of college students' quality. For the construction of campus culture, colleges and universities should first start with purifying and cleaning the surrounding environment of the campus. They should dabble in every aspect from the material environment to the spiritual environment. Colleges and universities in the material environment can set up celebrity sculptures and decorate cultural corridors, set up a cultural exchange platform, post the school spirit, school regulations and school motto in the publicity column to create a distinctive campus cultural atmosphere and a good campus environment. Mental environment colleges and universities can publicize campus culture, socialist core values, ideology and morality through the Internet to train students to have correct values, outlook on life and world outlook. The ideological and ideological field has always been an important position for colleges and universities to firmly control. Under the new situation, colleges and universities rely on the concept of "moral cultivation" to comprehensively educate and guide students to set up the correct value orientation and cultivate new contemporary youth who are patriotic, honest, friendly and self-reliant (Jin \& Wang, 2019).

\subsection{Improve the Level of Teaching Management and Set an Example Benchmark}

While educating and managing students, university student management workers should put their own "teachers' ethics" and "teachers' style" in the first place in education and management. The construction of teachers' "ethics" and "teachers' style" is the most important link in the education system. Teachers are also taught to dispel doubts. This is a high generalization of the teaching profession in Chinese history, university teachers should have a very high sense of mission and responsibility. General Secretary Xi Jinping has also put forward the ardent hope of being a "four haves" good teacher for contemporary educators. The most important thing for a "four have" good teacher is to have ideals, beliefs 
and moral sentiments, Therefore, on the basis of carrying out the concept of "cultivating morality and cultivating people", colleges and universities should give top priority to the construction of teachers' morality and style. We will implement the Party's policies and principles and strive to enhance the initiative and creativity of educators. The training mechanism and system of "teacher's ethics" and "teacher's style" for managers will be strengthened. Universities will implement the "teacher's ethics" and "teacher's style" one-vote veto system in the year-end assessment and promotion of professional titles. Using centralized training to improve the theoretical level and service awareness of university managers, regular lectures on teachers' professional ethics are held, and typical advanced teachers' ethics are highlighted in publicity. The deeds of the recognized personnel are reported and studied, giving full play to the leading role of the list, and vigorously promoting moral construction.

\subsection{Promote the Reform of Management Mode and Perfect the Construction of Management System}

Colleges and universities implement the concept of "cultivating morality and cultivating people" as the guiding ideology, comprehensively promote the reform of student management mode and system improvement, construct the working mechanism of "cultivating morality and cultivating people" and form the unified leadership and deployment of high-efficiency Party committees: The working mode of coordination and co-management between the student affairs office and the communist youth league Committee is to create a cooperative and co-management system for specialized, part-time and temporary teams, and to form a leading group for moral cultivation, In order to promote the reform of the management mode of college students and build a management mode of student work that is in line with the characteristics of the times, the concept of "cultivating morality and cultivating people" is used to carry out all aspects of discipline construction, education and teaching, scientific research, student management and teaching evaluation in colleges and universities. At the same time, colleges and universities also need to use brand-new management concepts to promote the education of "cultivating morality and cultivating people", stimulate new vitality in student management and open up a new situation. Leading cadres in colleges and universities must take the lead in implementing and studying the basic connotation of "cultivating morality and cultivating people", strengthen internal research and deployment in schools, enhance the dominant position of "cultivating morality and cultivating people" in student management, and enhance the sense of responsibility and mission of all teaching and administrative staff, we call on the whole school to carry out the concept of "cultivating morality and cultivating people" and implement the special seminar on student management. The research results with practical value of mobile phones will be implemented into the student management system in colleges and universities to improve the construction of the student management system. 


\subsection{Deepening the Construction of Network Morality and Broadening the Ways of Cultural Communication}

The network has gradually become the second main position of higher education. With the development and application of "student work in internet plus", more and more education such as video conferences, special lectures, massive open online course, theoretical study and so on have begun to be carried out on the network platform. College students are also the main force in the Internet, Therefore, colleges and universities should make more use of the Internet to carry out cultural communication and ideological education of students. Colleges and universities should build a professional network management team. The members of the team must have high political consciousness, firm ideals and beliefs and strong professional skills. They should use the Internet as a platform to carry out various forms of network ideological and political education and teaching, and publicize campus culture through various platform channels. It plays a leading role in shaping the moral quality of college students. This team should include the publicity department of the university, the student affairs department, the youth league Committee, full-time and part-time counselors, members of the campus two-level new media studio and class publicity Committee. The composition of the team includes students and teachers at all levels. However, due to students' poor screening ability and self-discipline ability, teachers need to strictly check and review when updating content using the Internet platform. Through the network ideological and moral construction, it can provide a safe, harmonious, stable and positive platform and space for college students to study, live and grow healthily in body and mind.

Colleges and universities carry the fundamental task of cultivating high-quality talents for the country. On the basis of traditional teaching in the first classroom, the moral and aesthetic education in the second classroom and the first classroom blend into each other. And the daily student management model of "one-two classroom interaction" is being established by colleges and universities. Only two aspects go hand in hand. Only through common progress can the comprehensive and high-quality talents needed by the country be cultivated. Colleges and universities should firmly implement the fundamental position of "cultivating morality and cultivating people" and not waver. Combining with the actual situation of schools, colleges and universities should set out from reality to build a student management and training system, to enhance students' sense of identity and compliance with the management system, and to promote and assist the management of college students to achieve all-round, all-covering, healthy and harmonious development.

\section{Conflicts of Interest}

The authors declare no conflicts of interest regarding the publication of this paper.

\section{References}

Chen, L. J. (2019). Research on the Management of College Students under the Idea of 
Establishing Morality and Cultivating People. The Farm Staff, No. 19, 282.

Chen, X. N., \& Li, D. H. (2019). Research on the Mode of Counselor Education from the Perspective of Establishing Morality and Cultivating People. Think Tank Era, No. 34, 33-34.

Guo, Z. (2019). On the Optimization of College Students Affairs Management under the Background of Setting Up Morality and Cultivating People. New West, No. 26, 121-122.

Hu, Y. H., \& Si, K. D. (2019). On the Innovation of Ideological and Political Education of College Students from the Perspective of United Front Work. Journal of Zunyi Normal University, 21, 112-115.

Jin, D. R., \& Wang, Q. (2019). On the Reform and Practice of Educational Management in Colleges and Universities Based on Establishing Morality and Cultivating People. Heilongjiang Researches on Higher Education, 37, 77-80.

Jing, L., Yang, L. H., \& Teng, S. S. (2019). Establishing Morality and Cultivating People: The Basic Task of Ideological and Political Education for College Students. Course Education Research, No. 34, 64.

Wang, X. Y., \& He, M. Y. (2018). Exploration of the Way of the Yanan Spirit into the Ideological and Political Education of College Students. Journal of Zunyi Normal University, 20, 117-119.

$\mathrm{Xu}$, R. C. (2019). The Way to Carry out the Basic Task of "Establishing Morality and Cultivating People" in Colleges and Universities. Western China Quality Education, 5, 11-12.

$\mathrm{Xu}$, Y. (2019). Research on the Management of College Students Based on the Background of Establishing Morality and Cultivating People. Reading and Write Periodical, $16,46-47$.

Yi, Y. P. (2019). Reflections on the Reform of Ideological and Political Education in Colleges and Universities from the Perspective of Supply Side. Journal of Zunyi Normal University, 21, 109-112. 